\title{
Impact of Chilling Requirement on Budburst, Floral Development and Hormonal Level in Buds of Early and Late Apple Varieties (Malus sylvestris, Mill) under Natural Conditions
}

\author{
Mohamed A. Seif El-Yazal \\ Botany Department, Faculty of Agriculture, Fayoum University, Fayoum 63514, Egypt \\ mas04@fayoum.edu.eg
}

Keywords: Apple, Dormancy, Chilling requirements, Yield, indole-3-acetic acid (IAA), gibberellic acid $\left(\mathrm{GA}_{3}\right)$, abscisic acid $(\mathrm{ABA})$

\begin{abstract}
In order to produce the physiological bases for choosing early- flowering varieties that may avoid the insufficiently low winter temperatures, the early and late- opening apple varieties Barkhar, Local and Strakhan (Malus sylvestris) were investigated. The relation between the seasonal changes in endogenous hormones and flower buds opening date were studied. An improved understanding of the factors maybe managing budburst and development, and their underlying mechanisms is crucial for management of trees performance and fruit yield. This study investigated variations in chilling requirements, bud burst and development in early and late varieties of apple trees. The budburst and hormonal profile of flower and vegetative buds of early and late varieties were additionally investigated. Results showed less bud burst in late varieties than in early ones. In the former, promoters (indole-3-acetic acid and gibberellins) were increased at budburst. Although endogenous inhibitors levels of abscisic acid were considerably reduced by bud development in all varieties. We conclude that late varieties (Strakhan) are less economical in manufacturing new growth, as indicated by less bud vigor at budburst than early varieties (Barkhar and local) and show a marked differential hormonal level throughout bud development compared to early varieties.
\end{abstract}

\section{Introduction}

The majority of trees in temperate climates fulfills a chilling demand (CR) to overcome endodormancy and has a requirement of heat for flowering (Campoy et al. 2012). Chilling Hours $(\mathrm{CH})$ is that the easiest way to estimate chilling requirement. Therefore, the CR could dissent by species, varieties, or growing regions (Stino, 1995, Luedeling and Brown, 2011, Wang et al., 2012, Andreini et al., 2012). CR is one the major issue that determines the bloom date (Alburquerque et al., 2008). Cultivars with low CR bloom and ripen earlier, whereas those with high CR bloom and ripen later (Scorza and Okie, 1990, El-Shewy et al., 1999a). CR constrains the acceptable areas of cultivation of the various commercially important tree species and cultivars around the world. Previous studies have indicated that CR might be quantitative character controlled by minimum of one major sequence (Hauagge et al., 1991, El-Shewy et al., 1999b). Winter chill is associate agro environmental condition issue that integrates the length of cold periods also as prevailing temperature ranges. If chilling requirements don't appear to be met, irregular, delayed and asynchronous growth, flowering and fruit set can be found in subsequent season if chilling requirements don't appear (Luedeling et al., 2009, Campoy et al., 2011). One of the possible effects of temperature change can be a delay inside the beginning of chill accumulation; the fulfillment of chilling requirements and then the time at those trees become receptive to heat through spring. Since flower and leaf emergence result from a minimum of part consecutive fulfillments of cold ('chilling') and warm ('forcing') requirements, later and slower chilling accumulation should thus end in later flower and growth in spring (Luedeling et al., 2013).

Changes within the equilibrium of phytohormones are related to the onset, maintenance and removal of dormancy in seeds, buds, bulbs and tubers. At present, the molecular regulation of dormancy is poorly understood (Michalczuk, 2005). The relation of plant hormones and bud 
dormancy in additionally as bud break was a major down aspect for every theories and production practices. Seasonal changes in endogenous hormone during and after bud dormancy release was studied by many researchers (Guevara et al., 2008, Dong et al., 2009, Mornya and Cheng, 2011, Okay et al., 2011, Seif El-Yazal and Rady, 2014, Seif El-Yazal et al., 2014, 2018a, b, c \&d). They found that the incidence, termination, regulation and management of dormancy were regulated by hormones throughout sufficiently winter chilling requirement. Additionally, this research may help further studies to be performed on how chilling requirement affect changes in the length to full bud break, plant growth regulators and help to express the effect of endogenous growth regulators on flowering and yield

\section{Materials and Methods}

The 12-year-old trees of 'Barkhar, local and Strakhan' apple trees (Malus sylvestris Mill.) grafted on Malling-Merton 106 (MM 106) rootstock were designated randomized, for a preliminary study in 2015/2016 and for the most analysis studies within the 2016/2017 and 2017/2018 seasons. All trees were full-grown within the wood let (newly reclaimed saline chalky soil) of the Horticultural Station at Aboksah in Abshawai, Fayoum, Egypt. For the most 2-seasons study, designated trees of every selection $(n=6)$ were tagged in November 2015 and 2016, and sampled from September-March 2016/2017 and 2017/ 2018. Trees chosen for the study within the 1st season were not the identical trees that were designated for the second season. Each tree was designed as one replicate, and each variety included six trees (total $n=18$ ).

\section{Quantification of chilling requirements}

In this study, from Nov to March of next year in the orchard, apple branches from every variety were collected every 15 days and cultivated in artificial lighting setup with water to determine the bud dormancy releasing time (50\% bud break). Moreover, the quantity of chilling hours in the orchard (temperatures between 0 and $7.2^{\circ} \mathrm{C}$ ) throughout this period till the time of gap buds in every variety has been calculated (by using Thermograph). The foremost common chilling model, and one that is used wide, is the Chilling Hours Model, additionally referred to as the Weinberger Model (Bennett 1949, Weinberger 1950). This model that was first developed for peaches in Georgia (United States), interprets all hours with temperatures between 0 and $7.2{ }^{\circ} \mathrm{C}$ as effective for chilling accumulation. These chilling hours are accumulated through the winter season. Chilling hour's below $7.2^{\circ} \mathrm{C}$ from $1^{\text {st }}$ November to every opening date in three apple varieties beneath study throughout each 2016/2017 and 2017/2018 seasons had been determined (Table 1).

\section{Morphological characteristics and yield measurements on trees}

Bud count was created for every tree $(n=6)$ in each variety. The dates on which floral and vegetative buds started to open were recorded. Additionally, the dates at that flowering reached 25, 50,75 and $100 \%$ of the full flowers were calculated for every variety. The dormant buds were additionally counted and were expressed, with opened buds, as a proportion of the full number of buds. The ultimate fruit set was calculated 6 weeks after full bloom stage as a variety of persisted fruits per hundred spur and lateral buds (Westwood, 1978). At harvest stage, apple fruits were harvested, counted and weighed for every examined tree.

\section{Extraction and estimation of endogenous hormones in apple buds}

Bud samples were collected, 15-day intervals, starting from one September up to fifteen March for determining the hormonal content in buds. Buds were haphazardly sampled and right away transported to the laboratory. Vegetative and floral bud samples were taken from each tree of every variety and were analyzed for endogenous levels of indole-3-acetic acid (IAA), gibberellin $\left(\mathrm{GA}_{3}\right)$ and abscisic acid (ABA). The extraction and purification was conducted according to Kettner and Doerffling (1995). Samples (1.0 g fresh buds) were collected, from every variety, and ground, at $4{ }^{\circ} \mathrm{C}$, in $80 \%$ methanol alcohol containing $0.1 \mathrm{~g}^{-1}$ an antioxidant, butylated hydroxyl toluene (BHT). The hormones were extracted at $4{ }^{\circ} \mathrm{C}$ in dark for $72 \mathrm{~h}$ with subsequent modification of solvent. The extracted samples were centrifuged and therefore the supernatant was reduced to 
aqueous phase using exploitation rotary skinny film evaporator (RFE). The $\mathrm{pH}$ of aqueous phase was adjusted to 2.5-3.0 and divided three times with 1/3 volume of ethyl acetate. The ethyl acetate phase was dried completely using RFE. The dried sample was utterly exploited in $1 \mathrm{ml}$ of methanol (100\%) and was analyzed on HPLC (Shimadzu, C-R4A Chromatopac; SCL-6B system controller) using UV detector and C18 column (39 $9300 \mathrm{~mm}$ ). For identification of hormones, $100 \mu 1$ samples filtered through 0.45 millipore filters were injected into column. Pure IAA and GA3 (Sigma, USA) were used as standards for identification and quantification of those hormones. The identification was created on the idea of retention time and peak space of the standards. Methanol, acetic acid and water (30:1:70, respectively) were used as a mobile part. The rate of flow was adjusted at $0.5 \mathrm{ml}$ $\min ^{-1}$ with a mean time for fifteen min sample ${ }^{-1}$. The wavelength used for the detection of IAA was $280 \mathrm{~nm}$, whereas for $\mathrm{GA}_{3}$ was $254 \mathrm{~nm}$. For ABA, samples were injected onto a $\mathrm{C} 18$ column and eluted with a linear gradient of ethanol $(70 \%)$, containing $0.01 \%$ acetic acid, at a flow rate of $0.8 \mathrm{ml} \mathrm{min}^{-1}$. The retention time of ABA decided by using authentic standards, observance the extraction of normal at $254 \mathrm{~nm}$.

\section{Statistical analysis}

The values of the determined characters were subjected to statistical analysis according to the standard procedure described in (Gomez and Gomez,1984). The ' $F$ ' test was applied to assess the significance of the treatment at $5 \%$ level of probability

The values presented in the results obtained in this investigation are the mean of the two seasons under the study.

\section{Results}

Impact of winter chilling hours on bloom date

To confirm however the winter accumulated chilling hours affected the spring events; we tend to investigate the total bloom date $(50 \%$ bud break) once completely different numbers of controlled chilling hours. Data in Table (1) show that the dormancy releasing time of Barkhar, Local and Strakhan varieties were $2^{\text {nd }}$ of February, $23^{\text {rd }}$ February and $24^{\text {th }}$ March, after the accumulation of 232,276 and $283(\mathrm{CH})$ respectively in the first season and were $1^{\text {st }}$ of February, $1^{\text {th }}$ March and $27^{\text {th }}$ March, after the accumulation of 249,280 and $285(\mathrm{CH})$ respectively in the second season. There were about 21, 29 and 50 days difference in the first season, i.e., the occurrence of opening buds of Strakhan was 29 days later than that of Local and 50 days later than that of Barkhar in the first season and 27, 26 and 55 days difference in the second season and also the occurrence of opening buds of Strakhan was later than that of Local 26 days later and 55 days later than that of Barkhar in the second season, indicating that the chilling hours of Strakhan was higher than that of Local and Barkhar varieties. Strakhan varity needed more of chilling hours accumulative at low temperature $\left(7.2^{\circ} \mathrm{C}\right)$ than Barkhar and Local for bud break. Moreover, the sum accumulative low temperature (chilling hours) of bud break were step by step happy within the two varieties, Barkhar and Local opened in February and initial of March thanks to meeting the necessity of expeditiously accumulative low temperature $\left(\mathrm{CH} 7.2^{\circ} \mathrm{C}\right)$, whereas Strakhan still couldn't opened as a result of the expeditiously accumulative low temperature was but required for bud break $\left(\mathrm{CH} 7.2^{\circ} \mathrm{C}\right)$.

Table 1. Chilling accumulation (hours below $7.2^{\circ} \mathrm{C}$ ) from1 November to each break date for each variety during 2016/2017 and 2017/2018

\begin{tabular}{|c|c|c|c|c|}
\hline \multirow{3}{*}{ Varietes } & \multicolumn{3}{|c|}{ Hours under temperature7.2 ${ }^{\circ} \mathrm{C}$ from 1 November to 50\% bud break } \\
\cline { 2 - 5 } & \multicolumn{2}{|c|}{$2016 / 2017$} & \multicolumn{2}{c|}{$2017 / 2018$} \\
\cline { 2 - 5 } & Date of 50\% bud break & $\begin{array}{c}\text { Chilling } \\
\text { Hours }\end{array}$ & $\begin{array}{c}\text { Date of } 50 \% \text { bud } \\
\text { break }\end{array}$ & Chilling horse \\
\hline Barkhar & $2^{\text {nd }}$ February & 232 & $1^{\text {st }}$ February & 249 \\
\hline Local & $23^{\text {rd }}$ February & 276 & $1^{\text {st }}$ March & 280 \\
\hline Strakhan & $24^{\text {th }}$ March & 283 & $27^{\text {th }}$ March & 285 \\
\hline
\end{tabular}




\section{Date of floral bud break in the orchard}

With the buildup of low temperature, the chilling demand for fruit trees was step by step happy. Data in Table (2) indicated the dates to flowering (50\% flowering) 15 February, 16 March and 16 April for Barkhar, Local and Strakhan, respectively. The earliness reached about 60 and 31 days for Barkhar and Local apple varieties respectively as comparison with Strakhan variety.

Table 2. Date of flower bud opening and flowering period in apple varieties in the orchard

\begin{tabular}{ccccccc}
\hline & \multicolumn{5}{c}{ Date of flower bud opening } \\
\cline { 2 - 6 } Varieties & Beginning & $\begin{array}{c}25 \% \\
\text { flowering }\end{array}$ & $\begin{array}{c}50 \% \\
\text { flowering }\end{array}$ & $\begin{array}{c}75 \% \\
\text { flowering }\end{array}$ & $\begin{array}{c}\text { End of } \\
\text { flowering }\end{array}$ & $\begin{array}{c}\text { Flowering } \\
\text { period } \\
\text { (day) }\end{array}$ \\
\hline Barkhar & $10 \mathrm{Feb}$ & $13 \mathrm{Feb}$ & $15 \mathrm{Feb}$ & $17 \mathrm{Feb}$ & $24 \mathrm{Feb}$ & 14 \\
Local & $5 \mathrm{March}$ & $11 \mathrm{March}$ & 16 March & $19 \mathrm{March}$ & 23 March & 19 \\
Strakhan & 9 April & 11 April & 16April & 21 April & 26 April & 18 \\
\hline
\end{tabular}

Proportion of bud break and fruit set

Data presented in Table (3) indicated that early- opening apple varieties gave a high percentage of flower bud break and fruit set comparing with the late-opining apple variety. The proportion of flower bud break was 85.83 and $82.96 \%$ for Barkhar and Local apple varieties respectively as comparison with $72.17 \%$ for Strakhan variety. However, the percentage of fruit set was 58.53 and $37.05 \%$ for Barkhar and Local apple varieties respectively as comparison with $14.11 \%$ for Strakhan variety.

Table 3. Percentage of bud break, dormant buds and fruit set in three apple varieties

\begin{tabular}{|c|c|c|c|}
\hline Varieties & Bud break (\%) & Dormant buds (\%) & Fruit set (\%) \\
\hline Barkhar & $85.83 \mathrm{a}$ & $14.17 \mathrm{a}$ & $58.53 \mathrm{a}$ \\
Local & $82.96 \mathrm{~b}$ & $17.04 \mathrm{~b}$ & $37.05 \mathrm{~b}$ \\
Strakhan & $72.14 \mathrm{c}$ & $27.86 \mathrm{c}$ & $14.11 \mathrm{c}$ \\
\hline
\end{tabular}

Mean pairs followed by different letters are significantly different $(\mathrm{p}=0.05)$ by Duncan's test; $\mathrm{n}=6$

Number of fruit tree ${ }^{-1}$ and fruit yield

Data in Table (4) also show that, early-flower opening apple varieties (Barkhar and Local) have great number of apple fruits tree ${ }^{-1}$ and total fruit yield tree ${ }^{-1}$ when compared to the lateopening apple variety (Strakhan). Which exceeded by 94.12 and $69.03 \%$ for number of fruits tree ${ }^{-1}$ and 63.75 and $20.90 \%$ for fruit yield tree ${ }^{-1}$ in Barkhar and Local apple varieties respectively as comparison with Strakhan variety.

Table 4. Number of fruit tree ${ }^{-1}$ and yield per tree $(\mathrm{kg})$ in three apple varieties

\begin{tabular}{|c|c|c|}
\hline Varieties & No. of Fruit tree ${ }^{-1}$ & Yield per tree $(\mathrm{Kg})$ \\
\hline Barkhar & $424.17 \mathrm{a}$ & $25.02 \mathrm{a}$ \\
\hline Local & $369.34 \mathrm{~b}$ & $18.45 \mathrm{~b}$ \\
\hline Strakhan & $218.50 \mathrm{c}$ & $15.26 \mathrm{c}$ \\
\hline
\end{tabular}

Mean pairs followed by different letters are significantly different $(\mathrm{p}=0.05)$ by Duncan's test; $\mathrm{n}=6$

Indole acetic acid (IAA)

Relative amounts of IAA in the studied flower and vegetative buds of Barkhar, Local and Strakhan varieties throughout the concerned period are shown in Table (5).It is clear from the present data that IAA content in flower buds of Barkhar, Local and Strakhan apple varieties decreased gradually from the first sample ( $1^{\text {st }}$ of September) reaching its minimum content on the $15^{\text {th }}$ of November for Barkhar, $1^{\text {st }}$ of December in Local and $1^{\text {st }}$ of January for Strakhan varieties with some fluctuation. Thereafter, IAA content increased sharply towards the last sample (maximum content) in the three studied apple varieties. It is clear from the results mentioned above that IAA content reached its minimum content during deep dormancy then started to accumulate 
markedly during the early spring as buds opened. The same trend has been recorded in vegetative buds.

Table 5. Seasonal changes in the level of IAA ( $\mu$ g./ g. D.W.) in vegetative (V) and flower buds (F) of three apple varieties during and after release from dormancy

\begin{tabular}{|c|c|c|c|c|c|c|}
\hline \multirow{2}{*}{ Dates } & \multicolumn{9}{|c|}{ "Barieties } \\
\cline { 2 - 7 } & \multicolumn{2}{|c|}{ "Barkhar" } & \multicolumn{2}{c|}{ "Local" } & \multicolumn{2}{c|}{ "Strakhan" } \\
\cline { 2 - 7 } & V. & F. & V. & F. & V. & F. \\
\hline $1 / 9$ & $4.15 \mathrm{a}$ & $5.51 \mathrm{a}$ & $6.85 \mathrm{a}$ & $6.41 \mathrm{a}$ & $8.04 \mathrm{a}$ & $7.29 \mathrm{a}$ \\
\hline $15 / 9$ & $3.95 \mathrm{a}$ & $4.61 \mathrm{~b}$ & $6.35 \mathrm{a}$ & $6.31 \mathrm{a}$ & $7.85 \mathrm{a}$ & $7.29 \mathrm{a}$ \\
\hline $1 / 10$ & $2.18 \mathrm{~b}$ & $1.52 \mathrm{c}$ & $6.24 \mathrm{a}$ & $6.10 \mathrm{a}$ & $6.14 \mathrm{a}$ & $5.81 \mathrm{~b}$ \\
\hline $15 / 10$ & $1.98 \mathrm{~b}$ & $1.26 \mathrm{c}$ & $6.01 \mathrm{a}$ & $5.20 \mathrm{~b}$ & $4.02 \mathrm{~b}$ & $4.66 \mathrm{~b}$ \\
\hline $1 / 11$ & $1.25 \mathrm{~d}$ & $1.16 \mathrm{~d}$ & $4.18 \mathrm{~b}$ & $4.54 \mathrm{~b}$ & $2.99 \mathrm{c}$ & $3.50 \mathrm{c}$ \\
\hline $15 / 11$ & $1.49 \mathrm{c}$ & $1.36 \mathrm{c}$ & $2.02 \mathrm{c}$ & $2.26 \mathrm{c}$ & $2.15 \mathrm{c}$ & $2.26 \mathrm{c}$ \\
\hline $1 / 12$ & $1.10 \mathrm{~d}$ & $0.86 \mathrm{~d}$ & $0.78 \mathrm{~d}$ & $0.85 \mathrm{~d}$ & $1.45 \mathrm{~d}$ & $1.85 \mathrm{~d}$ \\
\hline $15 / 12$ & $1.84 \mathrm{~b}$ & $1.42 \mathrm{c}$ & $1.54 \mathrm{c}$ & $1.29 \mathrm{~d}$ & $1.09 \mathrm{~d}$ & $1.84 \mathrm{~d}$ \\
\hline $1 / 1$ & $1.95 \mathrm{~b}$ & $1.86 \mathrm{c}$ & $1.66 \mathrm{c}$ & $1.30 \mathrm{~d}$ & $0.85 \mathrm{~d}$ & $1.28 \mathrm{~d}$ \\
\hline $15 / 1$ & $3.99 \mathrm{a}$ & $4.77 \mathrm{a}$ & $3.04 \mathrm{~b}$ & $2.08 \mathrm{c}$ & $3.89 \mathrm{~b}$ & $3.51 \mathrm{c}$ \\
\hline $1 / 2$ & $4.15 \mathrm{a}$ & $4.89 \mathrm{a}$ & $3.25 \mathrm{~b}$ & $3.02 \mathrm{c}$ & $4.15 \mathrm{~b}$ & $3.90 \mathrm{~b}$ \\
\hline $15 / 2$ & ------- & --------- & $6.17 \mathrm{a}$ & $5.19 \mathrm{~b}$ & $4.91 \mathrm{~b}$ & $4.08 \mathrm{~b}$ \\
\hline $1 / 3$ & -------- & --------- & $7.56 \mathrm{a}$ & $6.88 \mathrm{a}$ & $7.18 \mathrm{a}$ & $6.96 \mathrm{a}$ \\
\hline $15 / 3$ & -------- & ------- & ------ & ------ & $7.25 \mathrm{a}$ & $7.88 \mathrm{a}$ \\
\hline
\end{tabular}

Mean pairs followed by different letters are significantly different $(\mathrm{p}=0.05)$ by Duncan's test; $\mathrm{n}=6$

Mean difference between dates of sampling

\section{Gibberellic acid}

Table (6) represent the fluctuation in the content of $\mathrm{GA}_{3}$ in the flower and vegetative buds. It is evident that GA3 content in Barkhar, Local and Strakhan apple varieties increased gradually from ( $1^{\text {st }}$ of September) till $15^{\text {th }}$ of October in Barkhar, $1^{\text {st }}$ October in Local and $1^{\text {st }}$ of November for Strakhan varieties, followed with marked decrease reaching its minimum content on the $15^{\text {th }}$ of November for Barkhar, $1^{\text {st }}$ of December in Local and $1^{\text {st }}$ of January in Strakhan varieties. Thereafter it increased markedly reaching its most content within the last sample (maximum content) altogether the three studied apple varieties. It's worthy to notice that the goodish increase within the level of $\mathrm{GA}_{3}$ was evident throughout the active growth period. On contrast they were poorly low through the period of retarded growth. The same trend was observed in vegetative buds.

Table 6. Seasonal changes in the level of GA 3 ( $\mu$ g./ g. D.W.) in vegetative(V) and flower buds (F) of the three apple varieties during and after release from dormancy

\begin{tabular}{|c|c|c|c|c|c|c|}
\hline \multirow{2}{*}{ Dates } & \multicolumn{3}{|c}{ "Barkhar" } & \multicolumn{2}{c|}{ "Larieties } \\
\cline { 2 - 7 } & V. & F. & V. & F. & V. & F. \\
\cline { 2 - 7 } & $1.74 \mathrm{~b}$ & $1.13 \mathrm{c}$ & $4.02 \mathrm{~b}$ & $3.93 \mathrm{~b}$ & $2.47 \mathrm{c}$ & $2.14 \mathrm{c}$ \\
\hline $1 / 9$ & $1.84 \mathrm{~b}$ & $1.14 \mathrm{c}$ & $5.09 \mathrm{a}$ & $4.56 \mathrm{a}$ & $2.98 \mathrm{c}$ & $2.94 \mathrm{c}$ \\
\hline $15 / 9$ & $1.95 \mathrm{~b}$ & $1.52 \mathrm{~b}$ & $5.21 \mathrm{a}$ & $5.95 \mathrm{a}$ & $4.55 \mathrm{~b}$ & $4.22 \mathrm{~b}$ \\
\hline $1 / 10$ & $2.01 \mathrm{~b}$ & $1.61 \mathrm{~b}$ & $4.14 \mathrm{~b}$ & $4.49 \mathrm{a}$ & $5.38 \mathrm{~b}$ & $5.18 \mathrm{a}$ \\
\hline $15 / 10$ & $1.18 \mathrm{c}$ & $1.23 \mathrm{c}$ & $3.81 \mathrm{~b}$ & $3.77 \mathrm{~b}$ & $6.21 \mathrm{a}$ & $5.95 \mathrm{a}$ \\
\hline $1 / 11$ & $0.94 \mathrm{~d}$ & $0.71 \mathrm{~d}$ & $1.54 \mathrm{c}$ & $1.32 \mathrm{c}$ & $3.18 \mathrm{~b}$ & $2.82 \mathrm{c}$ \\
\hline $15 / 11$ & $1.11 \mathrm{c}$ & $0.95 \mathrm{~d}$ & $1.01 \mathrm{~d}$ & $0.69 \mathrm{~d}$ & $1.97 \mathrm{~d}$ & $1.62 \mathrm{~d}$ \\
\hline $1 / 12$ & $1.25 \mathrm{c}$ & $1.05 \mathrm{c}$ & $1.86 \mathrm{c}$ & $1.15 \mathrm{c}$ & $1.84 \mathrm{~d}$ & $1.52 \mathrm{~d}$ \\
\hline $15 / 12$ & $1.30 \mathrm{c}$ & $1.10 \mathrm{c}$ & $2.48 \mathrm{~b}$ & $2.69 \mathrm{~b}$ & $1.25 \mathrm{~d}$ & $1.14 \mathrm{~d}$ \\
\hline $1 / 1$ & $1.52 \mathrm{~b}$ & $1.64 \mathrm{~b}$ & $2.98 \mathrm{~b}$ & $2.93 \mathrm{~b}$ & $1.47 \mathrm{~d}$ & $1.36 \mathrm{~d}$ \\
\hline $15 / 1$ & $3.93 \mathrm{a}$ & $4.47 \mathrm{a}$ & $6.87 \mathrm{a}$ & $6.52 \mathrm{a}$ & $3.98 \mathrm{~b}$ & $3.51 \mathrm{~b}$ \\
\hline $1 / 2$ & -------- & -------- & $7.01 \mathrm{a}$ & $6.89 \mathrm{a}$ & $4.75 \mathrm{~b}$ & $4.65 \mathrm{~b}$ \\
\hline $15 / 2$ & ------- & ------- & $7.33 \mathrm{a}$ & $6.95 \mathrm{a}$ & $7.04 \mathrm{a}$ & $6.98 \mathrm{a}$ \\
\hline $1 / 3$ & -------- & ------- & ------- & ------- & $7.23 \mathrm{a}$ & $7.05 \mathrm{a}$ \\
\hline $15 / 3$ & & & & &
\end{tabular}

Mean pairs followed by different letters are significantly different $(\mathrm{p}=0.05)$ by Duncan's test; $\mathrm{n}=6$

Mean difference between dates of sampling 


\section{Abscicic acid}

It is clear from the data in Table (7) that ABA content in flower and vegetative buds gradually decreased from the first sample $\left(1^{\text {st }}\right.$ of September) till $1^{\text {st }}$ October in Barkhar and till $1^{\text {st }}$ of November in both Local and Strakhan variety followed with marked increase reaching its maximum content on the $15^{\text {th }}$ of November in Barkhar, $1^{\text {st }}$ of December for Local and $1^{\text {st }}$ of January for Strakhan apple varieties. Thereafter it decreased in the three studied apple varieties reaching its minimum content in the last sample.

Table 7. Seasonal changes in the level of ABA ( $\mu$ g./ g. D.W.) in vegetative (V) and flower buds (F) of three apple varieties during and after release from dormancy

\begin{tabular}{|c|c|c|c|c|c|c|}
\hline \multirow{3}{*}{ Dates } & \multicolumn{6}{|c|}{ Varieties } \\
\hline & \multicolumn{2}{|c|}{ "Barkhar" } & \multicolumn{2}{|c|}{ "Local" } & \multicolumn{2}{|c|}{ "Strakhan" } \\
\hline & $\mathrm{V}$. & F. & $\mathrm{V}$. & F. & $\mathrm{V}$. & $\mathrm{F}$. \\
\hline $1 / 9$ & $0.35 \mathrm{~b}$ & $0.40 \mathrm{c}$ & $0.95 \mathrm{~d}$ & $0.81 \mathrm{c}$ & $0.30 \mathrm{~b}$ & $0.23 b$ \\
\hline $15 / 9$ & $0.30 \mathrm{~b}$ & $0.33 \mathrm{~b}$ & $0.89 \mathrm{~d}$ & $0.82 \mathrm{c}$ & $0.25 \mathrm{a}$ & $0.18 \mathrm{a}$ \\
\hline $1 / 10$ & $0.21 \mathrm{~b}$ & $0.18 \mathrm{a}$ & $0.66 \mathrm{c}$ & $0.54 b$ & $0.18 \mathrm{a}$ & $0.16 \mathrm{a}$ \\
\hline $15 / 10-$ & $0.31 \mathrm{~b}$ & $0.34 \mathrm{~b}$ & $0.42 \mathrm{~b}$ & $0.30 \mathrm{a}$ & $0.19 \mathrm{a}$ & $0.14 \mathrm{a}$ \\
\hline $1 / 11$ & $0.49 \mathrm{c}$ & $0.48 \mathrm{c}$ & $0.30 \mathrm{~b}$ & $0.25 \mathrm{a}$ & $0.28 \mathrm{~b}$ & $0.24 b$ \\
\hline $15 / 11$ & $0.85 \mathrm{~d}$ & $0.91 \mathrm{~d}$ & $0.65 \mathrm{c}$ & $0.79 \mathrm{c}$ & $0.31 b$ & $0.28 b$ \\
\hline $1 / 12$ & $0.67 \mathrm{c}$ & $0.71 \mathrm{~d}$ & $0.98 \mathrm{~d}$ & $0.96 \mathrm{~d}$ & $0.29 b$ & $0.27 \mathrm{~b}$ \\
\hline $15 / 12$ & $0.59 \mathrm{c}$ & $0.46 \mathrm{c}$ & $0.86 \mathrm{~d}$ & $0.91 \mathrm{~d}$ & $0.71 \mathrm{~d}$ & $0.82 \mathrm{~d}$ \\
\hline $1 / 1$ & $0.35 b$ & $0.29 \mathrm{~b}$ & $0.41 \mathrm{~b}$ & $0.31 \mathrm{a}$ & $0.81 \mathrm{~d}$ & $0.84 \mathrm{~d}$ \\
\hline $15 / 1$ & $0.12 \mathrm{a}$ & $0.18 \mathrm{a}$ & $0.22 \mathrm{a}$ & $0.27 \mathrm{a}$ & $0.65 \mathrm{c}$ & $0.58 \mathrm{c}$ \\
\hline $1 / 2$ & $0.11 \mathrm{a}$ & $0.17 \mathrm{a}$ & $0.19 \mathrm{a}$ & $0.23 \mathrm{a}$ & $0.32 b$ & $0.43 \mathrm{c}$ \\
\hline $15 / 2$ & |--------- & |--------- & $0.18 \mathrm{a}$ & $0.21 \mathrm{a}$ & $0.26 \mathrm{a}$ & $0.27 \mathrm{~b}$ \\
\hline $1 / 3$ & --------- & --------- & $0.17 \mathrm{a}$ & $0.20 \mathrm{a}$ & $0.22 \mathrm{a}$ & $0.18 \mathrm{a}$ \\
\hline $15 / 3$ & ---------- & ---------- & --------- & ---------- & $0.21 \mathrm{a}$ & $0.20 \mathrm{a}$ \\
\hline
\end{tabular}

Mean pairs followed by different letters are significantly different $(\mathrm{p}=0.05)$ by Duncan's test; $\mathrm{n}=6$ Mean difference between dates of sampling

\section{Indole acetic acid /abscicic acid ratio}

Data in Table (8) indicated the ratio of IAA/ABA in the studied flower and vegetative buds of Barkhar, Local and Strakhan varieties throughout the opening period. It is clear from the present data that IAA/ABA ratio in flower buds are decreased gradually from the first sample $\left(1^{\text {st }}\right.$ of September) reaching its minimum content on the $1^{\text {st }}$ of December for Barkhar and Local and $1^{\text {st }}$ of January for Strakhan varieties with some fluctuation. Thereafter, IAA/ABA ratio increased sharply towards the last sample (maximum content) in the three studied apple varieties. It is clear from the results mentioned above that IAA/ABA ratio reached its minimum content during deep dormancy then started to accumulate markedly during the early spring as buds opened. Similar trend was recorded in vegetative buds. 
Table 8. Seasonal changes in the level of IAA/ABA ratio in vegetative (V) and flower buds(F) of three apple varieties during and after release from dormancy

\begin{tabular}{|c|c|c|c|c|c|c|}
\hline \multirow{2}{*}{ Dates } & \multicolumn{9}{|c|}{ "Barkhar" } & \multicolumn{2}{c|}{ "Local" } & \multicolumn{2}{c|}{ "Strakhan" } \\
\cline { 2 - 7 } & V. & F. & V. & F. & V. & F. \\
\cline { 2 - 7 } & $11.85 \mathrm{~b}$ & $13.77 \mathrm{~b}$ & $.692 \mathrm{c}$ & $7.91 \mathrm{c}$ & $26.80 \mathrm{~b}$ & $31.69 \mathrm{a}$ \\
\hline $1 / 9$ & $13.16 \mathrm{~b}$ & $13.96 \mathrm{~b}$ & $7.13 \mathrm{c}$ & $7.79 \mathrm{c}$ & $31.40 \mathrm{a}$ & $40.50 \mathrm{a}$ \\
\hline $15 / 9$ & $10.38 \mathrm{~b}$ & $8.44 \mathrm{c}$ & $9.45 \mathrm{~b}$ & $11.29 \mathrm{~b}$ & $34.11 \mathrm{a}$ & $36.31 \mathrm{a}$ \\
\hline $1 / 10$ & $6.38 \mathrm{c}$ & $9.00 \mathrm{c}$ & $14.30 \mathrm{~b}$ & $17.33 \mathrm{~b}$ & $21.15 \mathrm{~b}$ & $33.28 \mathrm{a}$ \\
\hline $15 / 10$ & $2.55 \mathrm{~d}$ & $.136 \mathrm{~d}$ & $13.93 \mathrm{~b}$ & $1.80 \mathrm{~d}$ & $10.67 \mathrm{~b}$ & $14.58 \mathrm{~b}$ \\
\hline $1 / 11$ & $.175 \mathrm{~d}$ & $3.31 \mathrm{~d}$ & $3.10 \mathrm{~d}$ & $8.07 \mathrm{c}$ & $6.93 \mathrm{c}$ & $8.07 \mathrm{c}$ \\
\hline $15 / 11$ & $.164 \mathrm{~d}$ & $1.21 \mathrm{~d}$ & $0.79 \mathrm{~d}$ & $1.07 \mathrm{~d}$ & $5.00 \mathrm{c}$ & $6.85 \mathrm{c}$ \\
\hline $1 / 12$ & $3.11 \mathrm{~d}$ & $1.40 \mathrm{~d}$ & $4.04 \mathrm{~d}$ & $1.41 \mathrm{~d}$ & $.153 \mathrm{~d}$ & $2.24 \mathrm{~d}$ \\
\hline $15 / 12$ & $5.57 \mathrm{c}$ & $6.41 \mathrm{c}$ & $1.79 \mathrm{~d}$ & $4.19 \mathrm{~d}$ & $1.04 \mathrm{~d}$ & $1.52 \mathrm{~d}$ \\
\hline $1 / 1$ & $33.25 \mathrm{a}$ & $26.50 \mathrm{a}$ & $13.81 \mathrm{~b}$ & $7.07 \mathrm{c}$ & $5.98 \mathrm{c}$ & $6.05 \mathrm{c}$ \\
\hline $15 / 1$ & $37.72 \mathrm{a}$ & $28.76 \mathrm{a}$ & $17.10 \mathrm{~b}$ & $13.13 \mathrm{~b}$ & $12.96 \mathrm{~b}$ & $9.06 \mathrm{~b}$ \\
\hline $1 / 2$ & -------- & --------- & $34.27 \mathrm{a}$ & $24.71 \mathrm{a}$ & $18.88 \mathrm{~b}$ & $15.11 \mathrm{~b}$ \\
\hline $15 / 2$ & ------- & -------- & $44.47 \mathrm{a}$ & $32.76 \mathrm{a}$ & $32.63 \mathrm{a}$ & $38.66 \mathrm{a}$ \\
\hline $1 / 3$ & ------------- & ----- & $34.52 \mathrm{a}$ & $39.40 \mathrm{a}$ \\
\hline $15 / 3$ & -------- & ---- &
\end{tabular}

Mean pairs followed by different letters are significantly different $(\mathrm{p}=0.05)$ by Duncan's test; $\mathrm{n}=6$

Mean difference between dates of sampling

\section{Gibberellic acid/abscicic acid ratio}

Table (9) represent the fluctuation in the ratio of $\mathrm{GA}_{3} / \mathrm{ABA}$ in the flower and vegetative buds. It is evident that $\mathrm{GA}_{3} / \mathrm{ABA}$ ratio in Barkhar, Local and Strakhan apple varieties increased gradually from $\left(1^{\text {st }}\right.$ of September) till $1^{\text {st }}$ of October in Barkhar, $1^{\text {st }}$ November in Local, and Strakhan varieties, followed with marked decrease reaching its minimum content on the $15^{\text {th }}$ of November for Barkhar , $1^{\text {st }}$ of December in Local, and $15^{\text {th }}$ of December in Strakhan varieties. Thereafter it increased markedly reaching its most content within the last sample (maximum content) altogether the three studied apple varieties. It's worthy to notice that the goodish increase within the level of $\mathrm{GA}_{3} / \mathrm{ABA}$ ratio was evident throughout the active growth amount. Whereas they were poorly low through the period of retarded growth. Similar trend was recorded in vegetative buds.

Table 9. Seasonal changes in the level of $\mathrm{GA}_{3} / \mathrm{ABA}$ ratio in vegetative $(\mathrm{V})$ and flower buds $(\mathrm{F})$ of the three apple varieties during and after release from dormancy

\begin{tabular}{|c|c|c|c|c|c|c|}
\hline \multirow{2}{*}{ Dates } & \multicolumn{9}{|c|}{ "Barkhar" } & \multicolumn{2}{c|}{ "Larieties } \\
\cline { 2 - 7 } & V. & F. & V. & F. & V. & F. \\
\cline { 2 - 7 } & $4.97 \mathrm{c}$ & $2.82 \mathrm{c}$ & $4.23 \mathrm{c}$ & $4.85 \mathrm{c}$ & $8.23 \mathrm{c}$ & $9.30 \mathrm{c}$ \\
\hline $1 / 9$ & $6.13 \mathrm{c}$ & $3.45 \mathrm{c}$ & $5.71 \mathrm{c}$ & $5.62 \mathrm{c}$ & $11.92 \mathrm{~b}$ & $16.33 \mathrm{c}$ \\
\hline $15 / 9$ & $9.28 \mathrm{~b}$ & $8.44 \mathrm{~b}$ & $7.89 \mathrm{c}$ & $11.04 \mathrm{~b}$ & $25.27 \mathrm{a}$ & $33.16 \mathrm{a}$ \\
\hline $1 / 10$ & $6.48 \mathrm{c}$ & $7.14 \mathrm{~b}$ & $9.85 \mathrm{~b}$ & $14.96 \mathrm{~b}$ & $28.13 \mathrm{a}$ & $37.00 \mathrm{a}$ \\
\hline $15 / 10$ & $1.38 \mathrm{~d}$ & $1.35 \mathrm{~d}$ & $12.70 \mathrm{~b}$ & $15.02 \mathrm{~b}$ & $22.17 \mathrm{~b}$ & $24.75 \mathrm{~b}$ \\
\hline $1 / 11$ & $1.10 \mathrm{~d}$ & $0.78 \mathrm{~d}$ & $2.36 \mathrm{~d}$ & $.167 \mathrm{~d}$ & $10.25 \mathrm{~b}$ & $10.07 \mathrm{c}$ \\
\hline $15 / 11$ & $1.65 \mathrm{~d}$ & $1.33 \mathrm{~d}$ & $1.03 \mathrm{~d}$ & $.071 \mathrm{~d}$ & $6.79 \mathrm{c}$ & $6.00 \mathrm{c}$ \\
\hline $1 / 12$ & $2.11 \mathrm{~d}$ & $2.28 \mathrm{c}$ & $2.16 \mathrm{~d}$ & $3.48 \mathrm{~d}$ & $2.59 \mathrm{~d}$ & $1.85 \mathrm{~d}$ \\
\hline $15 / 12$ & $3.71 \mathrm{c}$ & $3.79 \mathrm{c}$ & $6.04 \mathrm{c}$ & $8.67 \mathrm{~b}$ & $1.54 \mathrm{~d}$ & $4.75 \mathrm{~d}$ \\
\hline $1 / 1$ & $12.66 \mathrm{~b}$ & $9.11 \mathrm{~b}$ & $13.54 \mathrm{~b}$ & $10.85 \mathrm{~b}$ & $2.26 \mathrm{~d}$ & $7.55 \mathrm{c}$ \\
\hline $15 / 1$ & $35.72 \mathrm{a}$ & $26.29 \mathrm{a}$ & $36.15 \mathrm{a}$ & $28.34 \mathrm{a}$ & $12.43 \mathrm{~b}$ & $27.00 \mathrm{~b}$ \\
\hline $1 / 2$ & ------- & -------- & $38.94 \mathrm{a}$ & $32.80 \mathrm{a}$ & $18.26 \mathrm{~b}$ & $25.83 \mathrm{~b}$ \\
\hline $15 / 2$ & -------- & -------- & $43.11 \mathrm{a}$ & $34.75 \mathrm{a}$ & $32.00 \mathrm{a}$ & $25.83 \mathrm{~b}$ \\
\hline $1 / 3$ & -------- & ------- & ------- & -------- & $34.42 \mathrm{a}$ & $44.00 \mathrm{a}$ \\
\hline $15 / 3$ & & & & & \\
\hline
\end{tabular}

Mean pairs followed by different letters are significantly different $(p=0.05)$ by Duncan's test; $n=6$

Mean difference between dates of sampling 


\section{Discussion}

It is clear nowadays that a wide variety of factors can break dormancy, in particularly environmental and hormonal influences have to be analyzed to understand the complex mechanism which start when the bud resume growth. During the process of bud dormancy releasing to bud break, many seasonal changes in some chemical constituents of buds, especially, endogenous hormones played a vital role in regulating dormancy and bud break, but current studies mainly focused on the dormancy and bud break of buds (Dong et al., 2009). Low temperature accumulation in dormancy stage was indispensable to bud break for deciduous fruit trees (Table 1). Such models as (chilling hours Below $7.2^{\circ} \mathrm{C}$ ) model, was the main dormancy releasing model (Weinberger, 1950), and their accuracy for determining the dormancy releasing time was probably influenced by specific environmental conditions due to lacking of the basis of physiological process. Throughout the method of bud dormancy cathartic to bud break, several physiological and biochemical indexes modified considerably in bud, like starch content, soluble sugar content, vital sign, metastasis pathways, protein content, amino acid content, bound water/free water quantitative relation, membrane consistence, etc. Especially, endogenous hormones played a vital role in regulating dormancy and bud break (Table 5, $6 \& 7$ ), but current studies mainly focused on the dormancy and bud break of buds. Hormone helped plants responding to environmental signals (Horvath et al. 2003). IAA might have a bearing on transcription of nuclear DNA that may contribute to cell enlargement, promote fruit development, and are concerned in apical dominance. The endogenous gibberellins additionally concerned the dormancy-releasing and early sprout growth in apple buds (Seif El-Yazal et al., 2018 c). The control of apple bud dormancy induction, maintenance and release therefore is mediated, at least in part, by changes in hormone signaling as it is also known for tree bud dormancy (El-Shewy et al.,1999 c\&d, Horvath et al., 2003, Rohde et al., 2007). In this connection, Duan et al. (2005) reported that GA3 concentration in cherry flower buds was reported to increase significantly inside the dormancy cathartic procedure and up to at the peak at terrible high speed before complete dormancy discharged. The rise within the endogenous content of bioactive $\mathrm{GA}_{1}$ is not related to bud dormancy unharness, however with insurant bud sprouts growth (Suttle, 2004, Hartmann et al., 2011). Moreover, Sun (2006) found on Lilium davidii power unit Unicol that substances changes in mother scales were regulated by endogenous $\mathrm{GA}_{3}$, whereas largely by endogenous ABA in female off spring scales. With the cathartic of dormancy, growth-promoting hormones like $\mathrm{GA}_{3}$ and IAA accumulated stepwise, whereas growth-inhibiting hormones like $\mathrm{ABA}$ faded. $\mathrm{GA}_{3}$ and $\mathrm{ABA}$ had the identical material substance MVA (Me-Valonic acid) for his or her synthesis and so the increasing lighting time promoted the synthesis of $\mathrm{GA}_{3}$ in buds (Dong et al., 2009). Results in Table (6) indicated that GA 3 concentration in bud of Barkhar and Local when dormancy cathartic was on top of that of Strakhan. During the whole testing period, IAA, GA3, IAA/ABA and $\mathrm{GA}_{3} / \mathrm{ABA}$ concentrations in buds of three apple varieties at their release from dormancy was higher than those of before bud break. In contrast, ABA concentration in buds was higher before bud break than that of at dormancy releasing (Table 5,6,78 \&9). In this concern, $\mathrm{Tu}$ and Ding (2003) found that, within the process from dormancy to bud break, GA $3 / \mathrm{ABA}$ ratios of Toona sinensis buds initial faded and so augmented. Also, gibberellic acid $\left(\mathrm{GA}_{3}\right)$ and $\mathrm{ABA}$ signaling as well as $\mathrm{GA}_{3} / \mathrm{ABA}$ ratios are important as known for tree bud sprouting (Horvath et al. 2003; Rohde et al. 2007). GA3 might promote the synthesis of sure mRNA and enzymes and increased the activity of certain enzymes like proteolytic enzyme, RNase and isocitrate lyase etc. Considering at the molecular level, it'd undoubtedly that there are existed associate unknown issue cooperating with $\mathrm{GA}_{3}$ to alleviate the inhibiting state and guaranteed the transcribing methodology of sequence equine as promoted the synthesizing of mRNA and molecule. GA3 might unleash dormancy and promote germinating for it might remove the inhibiting factors of sure mRNA (Suttle, 2004, Alexopoulos et al., 2008). With the alternative result, ABA might assembly of sure RNA indispensable to the synthesis of $\alpha$-amylase, and so the most role of ABA at intervals the method of germination was restraining GA and inflicting the transforming of reserve substance (Gubler, 2005). Once Barkhar opened in midFebruary, concentration of $\mathrm{GA}_{3}$ in Barkhar was higher, because the total with efficiency 
accumulative of low temperature $\left(\mathrm{CH} 7.2^{\circ} \mathrm{C}\right)$ meet the necessity of dormancy unleash, the concentration of ABA was lower, that resulted within the magnitude relation of $\mathrm{GA}_{3} / \mathrm{ABA}$ was higher (Table 9). Our results showed that when the dormancy released, IAA/ABA ratio had the same changing tendency to IAA content (Table 8). So, it could be presumed that IAA/ABA and $\mathrm{GA}_{3} / \mathrm{ABA}$ ratio determined the metabolism direction. In this concern, Dong et al. (2009) suggested that the ratios of IAA/ABA and GA3/ABA in apple buds were decreased in dormant buds, while increased in opening ones, which the balance of several hormones played a more important role than the level of certain single hormone in the procedure of dormancy releasing and opining of buds.

\section{Conclusion}

Accumulation of chilling hours in the winter was effect on dormancy release throughout the effect on the concentration of plant hormones. In late-opened variety Strakhan the chilling requirements was much higher than that in early-opened varieties Barkhar and Local at bud break. Strakhan needed high level of growth-promoting hormones to opened, such as $\mathrm{GA}_{3}$ and IAA. The high levels of $\mathrm{GA}_{3}$ and IAA concentration in Barkhar and Local at bud break led to significantly higher $\mathrm{GA}_{3} / \mathrm{ABA}$ and $\left(\mathrm{GA}_{3}+\mathrm{IAA}\right) / \mathrm{ABA}$ ratios than in Strakhan. Finally, from the results of the present investigation, it could be concluded that, under sufficient chilling requirements, growthpromoting hormones (IAA and $\mathrm{GA}_{3}$ ) were increased from dormancy initiation to dormancy release which decreased during deep dormancy and increased with bud break. In contrast growth-inhibitor hormones ABA was decreased from dormancy initiation to dormancy release which increased during deep dormancy and decreased with bud break

\section{References}

[1] Alburquerque, N., Garca-Montiel, F., Carrillo, A., Burgos, L. (2008). Chilling and heat requirements of sweet cherry cultivars and the relationship between altitude and the probability of satisfying the chill requirements. Environmental and Experimental Botany, 64, $162-170$.

[2] Alexopoulosa, A.A., Aivalakis, G., Akoumianakisa, K.A., Passama,H.C.(2008). Effect of gibberellic acid on the duration of dormancy of potato tubers produced by plants derived from true potato seed. Postharvest Biology and Technology, 49, 424-430.

[3] Andreini, L., Viti, R., Bartolini, S., Ruiz, D., Egea, J., Campoy, J.A. (2012).The relationship between xylem differentiation and dormancy evolution in apricot flower buds (Prunus armeniaca L.): the influence of environmental conditions in two Mediterranean areas. Trees, 26,919-928.

[4] Bennett, J.P. (1949). Temperature and bud rest period. Calif Agric, 3 (11), 9-12.

[5] Campoy, J.A., Ruiz, D., Egea, J. (2011). Dormancy in temperate fruit trees in a global warming context: a review. Sci Hortic., 130(2), 357-372. doi: 10.1016/j.scienta.2011.07.011. [CrossRef]

[6] Campoy, J. A., Ruiz, D., Allderman, L., Cook, N., Egea, J. (2012). The fulfillment of chilling requirements and the adaptation of apricot (Prunus armeniaca L.) in warm winter climates: An approach in Murcia (Spain) and the Western Cape (South Africa). European Journal of Agronomy, 37, 43-55.

[7] Dong, Q.I.N., Jin-Zheng, W.A.N.G., Jian-min, G.U.O., Heng, Z.H.A.I. (2009).The relation between endogenous hormones and late-germination in buds of avrolles apple. Agric. Sci. China, 8,564-571. 
[8] Duan, C. G., Li, X. L., Liu, H. F., Gao, D. S, Li, M. (2005). Effects of defoliation on endogenous hormones and active oxygen metabolism of sweet cherry flower buds during dormancy. Scientia Agricultura Scinica, 38, 203-207. (in Chinese)

[9] El- Shewy, A.A., Ibrahim, A.A., Zeid, F.A., El-Yazal, M. A. S. (1999a). Effect of some dormancy breaking components on blooming, fruit set, yield, yield components and physical and chemical properties of fruits of some apple cultivars. A. Blooming and fruit set. Annals of Agric. Sci., Moshtohor, 37(4), 2235 - 2246.

[10] El- Shewy, A.A., Ibrahim, A.A., Zeid, F.A., El-Yazal, M. A. S. (1999b). Effect of some dormancy breaking components on blooming, fruit set, yield, yield components and physical and chemical properties of fruits of some apple cultivars. Annals of Agric. Sci., Moshtohor, $37(4), 2247-2267$.

[11] El- Shewy, A.A., Ibrahim, A.A., Zeid, F.A., El-Yazal, M. A. S. (1999c). Effect of some dormancy breaking components on leaves and fruits chemical composition of some apple cultivars. 1. Chemical composition of leaves. Annals of Agric. Sci., Moshtohor, 37(4), 2269 2278 .

[12] El- Shewy, A.A., Ibrahim, A.A., Zeid, F.A., El-Yazal, M. A. S. (1999d). Effect of some dormancy breaking components on chemical composition of leaves and buds of some apple cultivars. 11. Chemical composition of vegetative and generative buds. Annals of Agric. Sci., Moshtohor, 37(4), 2279 - 2306.

[13] Gomez, K.A., Gomez, A.A. (1984). Statistical Analysis Procedure of Agricultural research. John Wiley and Sons, New York, pp. 25-30.

[14] Gubler, F., Millar, A.A., Jacobsen, J.V. (2005).Dormancy release, ABA and pre-harvest sprouting. Current Opinion in Plant Biology, 8, 183-187.

[15] Guevara, E., Jimene'z, V.M., Herrera, J., Bangerth, F. (2008). Effect of hydrogen cyanamide on the endogenous hormonal content of pea seedlings (Pisum sativum L.). Braz J. Plant Phys., 20,159-163.

[16] Hartmann, A., Senning, M., Hedden, P., Sonnewald, U., Sonnewald, S. (2011).Reactivation of meristem activity and sprout growth in potato tubers require both cytokinin and gibberellin. Plant Physiol., 155,776-796.

[17] Hauagge, R., Cummins, J. N. (1991). Genetics of length of dormancy period in Malus vegetative buds. Journal of the American Society for Horticultural Science, 116, 121-126.

[18] Horvath, D.P., Anderson, J.V., Chao, W.S., Foley, M.E. (2003). Knowing when to grow: signals regulating bud dormancy. Trends Plant Sci., 8, 534-540

[19] Kettner, J., Doerffling, K. (1995). Biosynthesis and metabolism of abscisic acid in tomato leaves infected with Botrytis cinerea. Planta, 196,627-634

[20] Luedeling, E., Blanke, M., Gebauer, J. (2009). Climate change effects on winter chill for fruit crops in Germany. Erwerbs-Obstbau., 51, 81-94. doi: 10.1007/s10341-009-0085-4. [CrossRef]

[21] Luedeling, E. and Brown, P. H. (2011). A global analysis of the comparability of winter chill models for fruit and nut trees. International Journal of Biometeorology, 55, 411-421.

[22] Luedeling, E., Kunz, A., Blanke, M.M. (2013). Identification of chilling and heat requirements of cherry trees-a statistical approaches. Int. J. Biometeorology, 57(5), 679-689.

[23] Michalczuk, L. (2005). Hormonal control of dormancy. International Journal of Fruit Science, 5(1), 59-73. 
[24] Mornya, P., Cheng, F. (2011). The levels of hormone and carbohydrate in autumn and nonautumn flowering tree peonies. Can. J. Plant Sci., 91, 991-998.

[25] Okay, Y., Günes, T.N., Köksal, A.I. (2011). Free endogenous growth regulators in Pistachio (Pistacia vera L.). African Journal of Agricultural Research, 6, 1161-1169.

[26] Rohde, A., Ruttink, T., Hostyn, V., Sterck, L., Van Driessche, K., Boerjan, W. (2007).Gene expression during the induction, maintenance, and release of dormancy in apical buds of poplar. Journal Experimental Botany, 58, 4047-4060.

[27] Scorza, R., Okie, W. R. (1990). Peaches (Prunus Persica L. Batsch). Acta Horticulturae, 290, $177-231$.

[28] Seif El-Yazal, M.A., Rady, M.M. (2014). Exogenous onion extract hastens bud break, positively alters enzyme activity, hormone, amino acids and phenol contents, and improves fruit quality in 'Anna' apple trees. Scientia Horticulturae, 169, 154-160.

[29] Seif El-Yazal, M.A., Seif El-Yazal, S.A., Rady, M.M. (2014). Exogenous dormancy-breaking substances positively change endogenous phytohormones and amino acids during dormancy release in 'Anna' apple trees. Plant Growth Regul.,72, 211-220.

[30] Seif El-Yazal, M.A., Rady, M.M., Seif El-Yazal, S.A.(2018a). Metabolic changes in polyamines, phenylethylamine, and arginine during bud break in apple flower buds under foliar-applied dormancy-breaking. International Journal for Empirical Education and Research, 1 (2), 1-18.

[31] Seif El-Yazal, M.A., Rady, M.M., Seif El-Yazal, S.A. (2018b). Foliar-applied mineral oil enhanced hormones and phenols content and hastened breaking bud dormancy in "Astrachan" apple trees. International Journal for Empirical Education and Research, 1 (2), 57-73.

[32] Seif El-Yazal, M.A., Seif El-Yazal, S.A., Rady, M.M. (2018c).Changes in promoter and inhibitor substances during dormancy release in apple buds under foliar-applied dormancybreaking agents. International Journal for Empirical Education and Research, 1 (4), 1-20.

[33] Seif El-Yazal, M.A., Rady, M.M., Seif El-Yazal, S.A., Morsi, M.E. (2018d).Changes in metabolic processes during break dormancy in apple buds under foliar-applied garlic extract. International Journal for Empirical Education and Research, 1(4), 36-58.

[34] Stino, G. R. (1995). Aspects related to temperature zone fruit production in Egypt. Acta Hort., 409, 203-204 .

[35] Sun, H.M., Li, T.L., Li, Y.F. (2006). Changes of endogenous hormones in Lilium davidiivar. unicolorbulbs during bulb development and storage at low temperature for dormancy release. Bulletin of Botanical Research, 26, 570-576. (in Chinese).

[36] Suttle, J.C. (2004). Involvement of endogenous gibberellins in potato tuber dormancy and early sprout growth: a critical assessment. Journal of Plant Physiology, 161, 157-164.

[37] Tu, B.K., Ding, X.F. (2003). Changes in endogenous hormones and carbohydrates from dormancy to sprouting of Toona sinensis buds. Scientia Silvae Sinicae, 39,159-161. (in Chinese).

[38] Wang, L. R., Zhu, G. R., Fang, W. C. (2012). Peach genetic diversity, origin, and evolution. In: Wang L R, Zhu G R, Fang W C, eds., Peach Genetic Resource in China. Chinese Agriculture Press, Beijing, China. p. 263. (in Chinese)

[39] Weinberger, J.H. (1950). Chilling requirements of peach varieties. Proc Am Soc. Hortic. Sci., $56,122-128$.

[40] Westwood, M.N. (ed) (1978). Dormancy and plant hardiness. In: Temperate zone pomology. Freeman, San Francisco, pp 299-319. 